\title{
Diasporas: Communities of Practice, Economies of Affect
}

\section{Niko Besnier}

It is at times of extreme public trauma that concepts like "community", "identity" and "cohesion" become the object of sustained attention. At the same time, this attention tends to be based on a naturalization of the concepts, the assumption that, on the one hand, these categories do not need to be defined or analyzed and, on the other hand, that they are morally positive, essentially good and important goals for all to pursue. What I would like to do in this brief intervention is to examine some of these assumptions and suggest ways in which we can better theorize our understanding of social action at times of intense trauma in the context of transnational dispersal and diverse connections.

Perhaps a fruitful point of departure is an examination of the oft-cited and seldom questioned concept "identity". Its genealogy in the social sciences encapsulates the complexities and contradictions that are embedded in the very concept itself. We generally associate the birth of a social scientific understanding of identity with developmental psychologist and psychoanalyst Erik Erikson's pivotal work, Identity and the Life Cycle (Erikson 1959). In this work, Erikson sought to capture the insight that, while people strive to maintain to themselves and to others a sense of continuity and growth, they go through life facing numerous and diverse challenges. As the challenges they face become more complex and diverse, people's sense of self increases in complexity. While Erikson focused primarily on the development of a psychological identity, he had also been strongly influenced by North American cultural anthropologists of his time; thus he recognized that persons are embedded in social groups and stressed that their sense of identity is as much the product of the people around them as the outcome of intra-personal development. Continuity in the context of change, person-internal as well as person-external, and the fragile play of divergent forces were integral to the concept of identity since its timid emergence in our analytic vocabulary, and militates for an approach to identity as a contingent, interactive and unfinished project. It has also motivated some scholars 
to argue that the concept is so fraught with problems (e.g. its instability as an analytic and experiential category) to completely undermine its usefulness or to replace it with another, more useful category like subjectivity (Brubaker et al. 2000: 1-47; Ortner 2005: 31-52).

Just as fragile and complex is our notion of "community", which of course goes much further in time than "identity", originating in the social sciences in the visions of Alexis de Tocqueville, Ferdinand Tönnies and Émile Durkheim (if not before). It is coming to us via a century's worth of sociological and anthropological thinking and writing, to late twentieth-century reclaimings of community in some social scientific and philosophical circles, as in the works of Robert Bellah and his colleagues Charles Taylor and Christopher Lasch (Bellah et al. 2007; Taylor 1989; Lasch 1979). Community and identity bear striking resemblances to one another; equally unstable, the two concepts are the subject of a great deal of romanticization of an idealized past in which social cohesion was made unproblematic by feelings of sameness (cf. both Durkheim and Karl Marx), as well as an idealized present and future, in which identity politics and the longing for community reify and fetishize them. Just as community is relentlessly portrayed as an "unequivocal good, an indicator of a high quality of life, a life of human understanding, caring, selflessness, belonging", identity is for many a must and forms the basis of claims to recognition, pushes for legal protection and personal feelings of pride and achievement (Joseph 2002: vii).

The relationship between identity and community, on the one hand, and what they are supposed to oppose, on the other, is fraught. Identity politics, based at once on the construction of sameness and difference, seeks to rectify past and present injustices in the form of oppression, denial of rights, and non-recognition. However, identity politics is also based on reified notions of authenticity and romanticized understandings of community. In fact, many invocations of community in the name of progressive causes and social justice fail to understand the extent to which they themselves are produced by the very source of inequality and lack of justice in society, namely capitalism (Against et al.2006: 3-22). Witness, for example, the extent to which racial, ethnic, sexual, and other forms of social differentiation that form the basis of a subaltern politics of liberation from 
oppression and marginalization are understood through acts of consumption, through the discrimination between those who belong and those who fail to belong, and through acts of power within the ranks of discriminated groups. Thus, for example, African-American identity politics in the United States (where identity politics was essentially invented) becomes co-opted by the consumption of "Afrocentric" products, from textiles to music to names (Stoller 2002; Boateng 2004: 212-226). And nowhere is the importance of "who belongs and who does not" more strident than in criticisms of the current president of the United States for not being "black enough" by some and "not American" by others.

Now (as if all this were not complicated enough already), transnational movement creates additional complexities, particularly when this movement takes the shape of what we have come to call "diasporic dispersal". So it is to diasporas that I now turn. As is well known, the term itself is from Old Testament Greek. It was originally borrowed into English in the late-nineteenth century. (The $O x$ ford English Dictionary lists a first occurrence in 1876, and it appears in the 1881 edition of the Encyclopædia Britannica under the entry for "Israel".) For the next century, the term referred almost exclusively to the successive dispersals of Jews in the ancient world. It was only in the 1990 s that the term entered social scientific language, where it became associated with sociological and anthropological approaches to people's mobility that defied a simplistic understanding of migrations as movement from point $\mathrm{A}$ to point $\mathrm{B}$, followed by the relative integration of migrants into the social conditions of point $\mathrm{B}$ and their gradual disengagement from the social conditions of point A. At the time, a drive was afoot in understanding the movement of people not as a matter of "migration", which conforms to this simplistic model, but as "mobility" (Hannam et al. 2006: 1-22; Urry 2007). This considerably more dynamic concept allows for movement between not just two but multiple points, not only unidirectional movement but also backtracking and sidestepping, as well as a play of multiple allegiances and senses of belonging, all of which, if we believe globalization theorists, are new to the late twentieth century.

Diasporic situations involve all of these features, with a particular emphasis on a number of characteristics (Brubaker 2005: 1-19). The first and perhaps least 
controversial defining feature of a diaspora is dispersal to multiple destinations. In contrast to migrant populations following a predictable path determined by clear historical contingencies (e. g., Algerians moving to France after World War II), diasporas consist of people moving to different geographical points. The diaspora on which my own work focuses is a good example: since the 196os, Tongans have moved in relatively large numbers from their island kingdom in the South Pacific to New Zealand, Australia, Hawaii, and the Continental United States, as well as, in smaller numbers, to a vast list of destinations, including Japan, to the extent that very few countries of the world fail to count at least a small number of Tongans in residence. The effect is one of an "exploded" population, one that moves in the multiple points of the compass from their point of origin (Besnier 2011; Small 2011; Lee 2003). What plays a determinative role in the relative multiplicity of destinations are state borders and the legal and punitive regimes associated with them.

The second feature that characterizes diaspora is what Rogers Brubaker calls "boundary maintenance", namely the work that people do to distinguish themselves from those who are outside the group and by implication the work that they do to emphasize commonality and homogeneity within the group. Here, Brubaker bases himself on Norwegian anthropologist Fredrik Barth's classic and yet still profoundly relevant thesis that ethnicity is not the product of the internal properties of a group (e. g., symbols, physical appearance, practices, objects) but the product of action designed to distinguish the group from those outside the group with whom they come into contact (Barth 1969: 9-38). For Brubaker, diasporic citizens "work" to distinguish themselves from those around them and do so through various means: endogamy ("marry only someone from your group"), for example, as well as other forms of self-segregation.

In my own view, this is the weakest factor because it fails to distinguish the ideology of being different from the social practice of self-differentiation. Take endogamy in the context of the most canonical diaspora of all, namely the Jewish diaspora over the centuries. As is well known, for many centuries Jews in Europe held on to a strong ideology of endogamy and other forms of separation from mainstream society, and of course mainstream society returned the favor by ex- 
cluding Jews from institutions, spaces and structures of power, or by attempting to eliminate them. However, in his explosive book, The Invention of the Jewish People, originally published in Hebrew in 2008, Israeli historian Shlomo Sand has argued not only that European and Middle Eastern Jews were in constant and often cordial contact with their non-Jewish neighbors (something that was certainly the case in the multicultural Ottoman Empire that ruled over the Middle East for centuries) but also that most modern Jews descend from converts and inter-marriages (Sand 2009 and Wayland 2004: 405-426). It is only in the nineteenth century that Jewish intellectuals, inspired by Romantic constructions of the folk character of German nationalism, began constructing a history of the Jews as a wandering and separate people who would eventually return to the Promised Land. (As one can well imagine, the book created an uproar because it essentially destroys the basis of Zionist claims to land in Israel and Palestine and everything that stands on it.) For the purpose of our understanding of diasporas, it modulates the importance of a historically continuous sense of otherness as a necessary feature of diasporas.

The third and perhaps most interesting feature (as well as more directly relevant to the situation that this special issue focuses on) is a sustained orientation to the homeland, be it real or imagined. What "orientation" actually means remains vague in many representations. In the example that I have already provided, that of the Tongan diaspora, as well as many other cases like it, "orientation" is commonly measured or evaluated in terms of material support: for example, the classic "remittances" or sometimes substantial sums of money that mobile citizens send to their relatives, their churches or mosques, their villages, political parties or armies and militias (witness the support of the Tamil diaspora for the Tamil Tigers during the civil war in Sri Lanka) (Wayland 2004: 405-426).

In fact, the motivation for moving in many cases is predominantly the need and moral responsibility to support non-mobile co-citizens. These feelings of responsibility are often embedded in long-term structures of reciprocity and indebtedness, from the religious responsibility that Buddhism places on Thais to support their elders to the classic Maussian counter-gift that migrants owe to their families (or, in darker contexts, to human traffickers) who have financed 
their travels. This situation, of course, is much more relevant to diasporas that emanate from homelands where money is in short supply, employment is lacking, and, even if one finds employment, the income one generates even in highlevel local employment is considerably lower than the income one generates in low-level employment elsewhere. Thus, Filipino medical doctors find it preferable to work as nurses in Canada (where their medical doctors' qualifications are not recognized) than to work as doctors in the Philippines, despite the downward economic mobility that this decision represents (McElhinny et al. 2009: 93-110).

But there are other ways in which "orientation to a homeland" can manifest itself, and this is what is relevant here. If we replace "orientation" with "allegiance", namely the loyalty or commitment of a person to a group or a cause, then we can begin to encompass a broader range of diasporic situations, including the one focused in the present work. But, at the same time, allegiance is a slippery notion. What is the group or cause that I feel allegiance to? When I sent some money to the Red Crescent to help people who have lost loved ones and property in the Pakistani floods of 2010, am I expressing allegiance to a group or a cause, or simply expressing a humanistic sense of empathy for fellow human beings, no matter where they live, what religions they practice, and what conditions they live in? But is my act different than the money I sent to the Japanese Red Cross on March 2011, because of my much greater personal involvement with Japan than with Pakistan? Furthermore, allegiance can be complex, in that I can feel deep sorrow and empathy for people whose families and homes were obliterated by the tsunami, but how do I feel about the cronyism between state power and industrial power, colluding to keep Japanese people in the dark as to the real danger of radiation? Clearly, allegiance must be to something, and that something may vary greatly from one person to the other, from one group to the other, and from one moment to the next. That "something" certainly does not mean "country", a concept that conflates nation, state, the corporate world, and the kind of identity that the nihonjinron ("scholarship of Japanese uniqueness") industry would like us to believe operates in Japan. What these considerations imply is that feelings and action are closely bound together, and that people define themselves, define who they are in the context of a transnational "community", and by implication 
define what a diaspora is, in terms of "affect", a category that seeks to capture an essentially psychological phenomenon (otherwise known as "emotion" or "feeling") while emphasizing the extent to which this phenomenon is the motivation for action in response to other actions. The close relationship between affect and action helps us rethinking diasporic communities not so much as classic instances of Durkheimian or Tönniesian "communities", or even as instances of "imagined communities" that Benedict Anderson sees at the root of nationalism, but in terms of what has been termed "communities of practice" since the 1990s, a category thought up by cognitive anthropologists Jean Lave and Etienne Wenger to refer to a group of people who share a craft or a profession (Anderson 2006; Lave et al. 1991).

This concept has since been extended to refer to assemblages of persons (note my wording!) who aim for a common purpose and who are bound together by that purpose. A common purpose can, of course, be ephemeral, although it can also be a powerful rallying cry in our fragmented and dispersed world.

Common purpose also invokes ways of linking affect to practice that people recognize among one another. And from this emerges a fourth aspect of diasporas that Brubaker does not touch on (neither do other diaspora scholars, as far as I am aware): the fact that different diasporic nodes have a commonality of purpose. As several authors in this special issue document, transnational Japanese people's mobilization in response to the triple disaster linked together different overseas groups via social media, which I suggest can be analyzed as the development of a community of practice around affective responses to trauma. This certainly resonates with my ethnographic experience of how the Tongan diaspora operates, namely as a vast network of transnational links that tie together groups of people living across vast distances, through the multi-directional exchange of goods, money, people (grandmothers or small children traveling from one diasporic node to another), ideas, fashions, and, I suggest, affects. Affect is thus embedded in a complex and multi-scalar system in which actions have value in two general senses: materially ("a value") and ethically ("values"). These two understandings of value may bleed onto one another, as when material resources become the expression of ethical stance and vice versa. 
What emerges from this discussion of aspects of diasporas that have rarely been foregrounded is the central role that affect and the social practices that are related to affect play in the construction of diasporas as communities of practice. Thus affect is the link between inner states and social action, and it is inherently reflexive. It is through affect and the actions that derive from it that we become social and political subjects in response to the people around us. This has motivated some scholars to talk about "economies of affect", breaking down the separation between the materiality of economies and the symbolic nature of emotions, feelings and affects (Zelizer 2013; Narotzky et al. 2014: S4-S16). Centralizing the importance of affect in understanding diasporas helps us understand how the trauma of disaster, which generates particularly strong affects, is linked to the way in which people dispersed around the globe understand themselves, their relationship to each other and their relationship to what many still consider their homeland.

\section{Acknowledgments}

I thank Andreas Niehaus and the other organizers of the international conference "Transnational Responses to Catastrophe: Japanese Diaspora Communities and the March 2011 Triple Disaster" for having invited me to present an earlier version of this paper as a keynote address. I am grateful to Christian Tagsold for his comments on the draft. Some passages are revised versions of passages from my article "Communities and Identities: Fraught Categories and Anchoring Resources” (Besnier 2009: 167-171).

\section{Literature}

Against, Joseph; Creed, Gerald. 2006. "Reconsidering Community." In: Creed, Gerald (ed.): The Seductions of Community: Emancipations, Oppressions, Quandaries. Santa Fe, NM: School of American Research Press, pp. 3-22.

Anderson, Benedict. 2006. Imagined Communities: Reflections on the Origin and Spread of Nationalism. 2nd ed. London: Verso.

BARTH, Fredrik (ed.). 1969. Introduction to Ethnic Groups and Boundaries: The Social Organization of Cultural Difference. Oslo: Universitetsforlaget. 
Bellah, Robert; Madsen, Richard; Sullivan, William M.; Swidler, Ann; Tipton, Steven M. 2007. Habits of the Heart: Individualism and Commitment in American Life, 2nd ed. Berkeley: U of California P.

Besnier, Niko. 2009. "Communities and Identities: Fraught Categories and Anchoring Resources.” In: Reyes, Angela; Lo, Adrienne (eds.): Beyond Yellow English: Toward a Linguistic Anthropology of Asian Pacific America. New York: Oxford UP, pp. 167-171. Besnier, Niko. 2011. On the Edge of the Global: Modern Anxieties in a Pacific Island Nation. Stanford, CA: Stanford UP.

Boateng Boatema. 2004. "African Textiles and the Politics of Diasporic Identity-Making." In: Allman, Jean (ed.). Fashioning Africa: Power and the Politics of Dress. Bloomington: Indiana UP, pp. 212-226.

Brubaker, Rogers. 2005. “The 'Diaspora' Diaspora." In: Ethnic and Racial Studies 28: pp. $1-19$.

Brubaker, Rogers; CoOper, Frederick. 2000. "Beyond 'Identity". In: Theory and Society 29: pp. $1-47$.

ERIKSON, Erik. 1959. Identity and the Life Cycle: Selected Papers. New York: International Universities Press.

Hannam, Kevin; Sheller, Mimi; Urry, John. 2007. "Mobilities, Immobilities and Moorings.” In: Urry, John: Mobilities 1. Cambridge: Polity P., pp. 1-22.

Joseph, Miranda. 2002. Against the Romance of Community. Minneapolis: U of Minnesota Press.

Lasch, Christopher. 1979. The Culture of Narcissism: American Life in an Age of Diminishing Expectations. New York: W. W. Norton.

Lave, Jean; Wenger, Etienne. 1991. Situated Learning: Legitimate Peripheral Participation. Cambridge: Cambridge UP.

LeE, Helen. 2003. Tongans Overseas: Between Two Shores. Honolulu: U of Hawai'i P.

McElhinny, Bonnie; Damasco, Valerie; Yeung, Shirley; De Ocampo, Angela F.; Febria, Monina; Collantes, Christianne; SAlongA, Jason. 2009. “Talk about Luck”: Coherence, Contingency, Character, and Class in the Life Stories of Filipino Canadians in Toronto." In: Reyes, Angela; Lo, Adrienne (eds.): Beyond Yellow English: Toward a Linguistic Anthropology of Asian Pacific America. New York: Oxford UP., pp. 93-110.

Narotzky, Susana; Besnier, Niko. 2014. "Crisis, Value, and Hope: Rethinking the Economy." In: Current Anthropology 55: pp. 4-16.

Ortner, Sherry. 2005. "Subjectivity and Cultural Critique." In: Anthropological Theory 5: pp. 31-52.

SAnd, Shlomo. 2009. The Invention of the Jewish People. London: Verso.

Small, Cathy A. 2011. Voyages: From Tongan Villages to American Suburbs, 2nd ed., Ithaca, NY: Cornell UP. 
StOller, Paul. 2002. Money Has No Smell: The Africanization of New York City. Chicago: U Chicago P.

TAYLOR, Charles. 1989. Sources of the Self: The Making of Modern Identity. Cambridge, MA: Harvard UP.

WAYland, Sarah. 2004. "Ethnonationalist Networks and Transnational Opportunities: The Sri Lankan Tamil Diaspora." In: Review of International Studies 30: pp. 405-426. Zelizer, Viviana A. 2013. Economic Lives: How Culture Shapes the Economy. Princeton, NJ: Princeton UP. 